\title{
Intra-District Disparities in Primary Education: A Case Study of Bankura District, West Bengal
}

Krishnendu Maji ${ }^{+*}$ and Dr. Sumana Sarkar ${ }^{\top}$

\section{Abstract}

The level of education and its response to different educational opportunities vary from one spatial unit to another depending on various factors like social, economic, cultural, and institutional. It is understood that certain regions acquire relative advancements over others in terms of human resource development and human capital formation. The key purpose of this research is to examine the intra-district disparities in primary education in Bankura District one of the districts of West Bengal. It ranks $11^{\text {th }}$ among the 19 districts of West Bengal (Human Development Report, 2007). Overall literacy rate of the district stands at $70.26 \%$ but the district scores low in terms of female literacy rates, which is $60.05 \%$, whereas the male literacy rate is $80.05 \%$, which is a huge gender literacy gap of $20 \%$. There are also regional inequalities existing at block level. Kotulpur ranks first with a literacy rate of $78.01 \%$ while Saltora occupies the bottom position with literacy rate of just $61.45 \%$ (Census of India, 2011). The level of educational development is dependent on several factors-enrolment ratio, dropout and repetition rates, pupil-teacher ratio, habitations covered by educational institutions, space-student ratio, drinking water and sanitation facilities in school, etc. In this context, the present study aims at examining the issues of intra-district disparities in educational attainment with regard to various educational amenities of Bankura district, West Bengal. Ten attributes have been selected to examine the level of development in primary education. It is clear from the study that the level of development in eastern part of the district is relatively better in comparison to other regions. Economic backwardness and physical bottlenecks continue to be major issues in western blocks.

Key words: Educational Amenities, Literacy, Enrolment, Schools, Regional Disparities, Bankura District, West Bengal, India

\footnotetext{
${ }^{\dagger}$ M.Phil Scholar, Department of Geography, The University of Burdwan, Burdwan-713104, West Bengal, India, Email: krishnendumaji58@gmail.com

${ }^{*}$ Corresponding Author

'Assistant Professor, Department of Geography, The University of Burdwan, Burdwan-713104, West Bengal, India, E-mail: sumanasarkar83@gmail.com

(C) 2017 Maji and Sarkar. This is an Open Access article distributed under the terms of the Creative Commons Attribution License (http://creativecommons.org/licenses/by/2.0), which permits unrestricted use, distribution, and reproduction in any medium, provided the original work is properly cited.
} 


\section{Introduction}

The various dimensions of socio-cultural changes in any society can be understood in the light of the levels of literacy and education. Achievement of universal primary school attendance for boys and girls was one of the Millennium Development Goals (MDGs) approved of in September 2000 at a United Nations summit, which aimed at complete reduction of the existing gender gaps in literacy under Goal 2 (achieve universal primary education). It is well known that education plays a vital role in socio-economic progress of a developing country like India where the largest resources that it can command at any given time are its human power or human resource (Rahi, 1996). In the post-2015 period, the MDG goal is known as Sustainable Development Goal 4, which ensures quality, equitable and inclusive education aimed at promoting lifelong learning opportunities for all. After nearly two decades of independence, the first National Policy on Education (NPE) was announced by the then Prime Minister Smt. Indira Gandhi in 1968, which called for a 'radical restructuring' and equalisation of educational opportunities in order to achieve national integration and greater cultural and economic development. The next National Policy on Education (NPE) (1986) paid efforts not only to eliminate the social disparities entailed in the educational system but also to enhance the quality of the government funded schools (Bhattacharyya, 2009; Barooah, 2014). The NPE called for a 'child-centred approach' in the primary education system and launched 'Operation Blackboard' to improve the same nationwide (Ministry of Human Resource Development, 1986).In the 1990s (that is, in the 199394),Sarva Shiksha Abhiyan (SSA) with an objective of universalisation of primary education for all was floated with the launching of District Primary Education Programme (DPEP) alongside a funding made by the World Bank for establishments of schools in rural areas having easy access for the communities. Then the 86th Constitutional Amendment Act (with the insertion of Article
$21 \mathrm{~A}$ of the Indian Constitution) in 2002 mandates elementary education a fundamental right. Subsequently, SSA became operational since 2000-2001. It is actually a comprehensive flagship programme, which aimed at attaining universal elementary education in a time bound manner. It focuses mainly on access to quality education, social and gender equity imparted to all children (including the physically challenged) (Planning Commission, Government of India, May 2010). It thereby makes means provision of free and compulsory education to all children up to the age of 14 , which is a directive principle of the state policy incorporated in the Constitution of India (Bhattacharyya, 2009; Barooah, 2014). This was of course promulgated under Article 45 of the Constitution of India. In order to carry on the SSA model forward, on 4th August 2009; the Government of India enacted the Right to Education Act, (RTE) as per the Article $21 \mathrm{~A}$ of the Indian Constitution. With the enforcement of the RTE legislation on $1^{\text {st }}$ April 2010, India became of one of the 135 countries not only in making education a child's fundamental right but also on putting the responsibility of enrolment, attendance and completion of education on the government. Literacy rate in India has risen substantially from 52\% in 1991 to $74 \%$ in 2011. Despite the fact that decent progress has been made in universalisation of elementary education, as is evident from increased enrolment and higher literacy levels, the situation is still adverse in many areas characterised by wide gender gaps, large share of dropouts and absentee among the school going children. School enrolment in India is influenced by a variety of socioeconomic and cultural factors, but more importantly by government policy in providing school infrastructure. Although, the average literacy of West Bengal is $77 \%$, the districts in western and northern parts of the state have much lower literacy rates than the state and national average (Census of India, 2011). These districts not only supply the majority of the agricultural labourers of the state but also rank at the bottom of the Human Development Index (West Bengal Human Development 
Report, 2007). Further, most of these districts are severely backward in terms of health, infrastructure, employment and other facilities (West Bengal State Development Report, 2007).The current research aims at illustrating the level of development in primary education in Bankura district, West Bengal with respect to ten educational indicators. The structure of the paper has been divided into following sections. It begins with a rationale for selection of the study area including the objective of the study. This follows a brief description of database and methodology. It then goes on to discuss the spatial pattern of selected variables and their interrelationship with each other. It is to be noted here that in order to figure out the influence of one variable upon the others, a correlation matrix has been developed.

\section{Study Area}

Bankura is the fourth largest district of West Bengal located in the western part of the state, which is popularly known as 'Rarh' of Bengal delta. The district may be described as the 'connecting link between the plains of Bengal on the east and Chota Nagpur plateau on the west' (District Census Handbook, Bankura 2011: p9). The district is situated in between $22^{\circ} 38^{\prime}$ and $23^{\circ} 38^{\prime}$ north Latitude and $86^{\circ} 36^{\prime}$ and $87^{\circ} 47^{\prime}$ east Longitude (Figure 1). It is bounded by Paschim Medinipur in the south and Hooghly district in the north, Purulia district in the west, Burdwan (Now known as Bardhaman) district in the north and east (Figure 1). The district of Bankura acquired its present shape and dimension in 1879 though until 1881, the district judgeship was known as West Burdwan. It was given the name Bankura in 1881 and since then the administrative and judicial jurisdictions of the district have been coterminous with the geographical boundaries of Bankura.

Administratively, Bankura district is divided into three Sub-Divisions, viz. (1) Bankura (Sadar) (2) Bishnupur and (3) Khatra. There are 22 Community Development (C.D.) Blocks in the district.

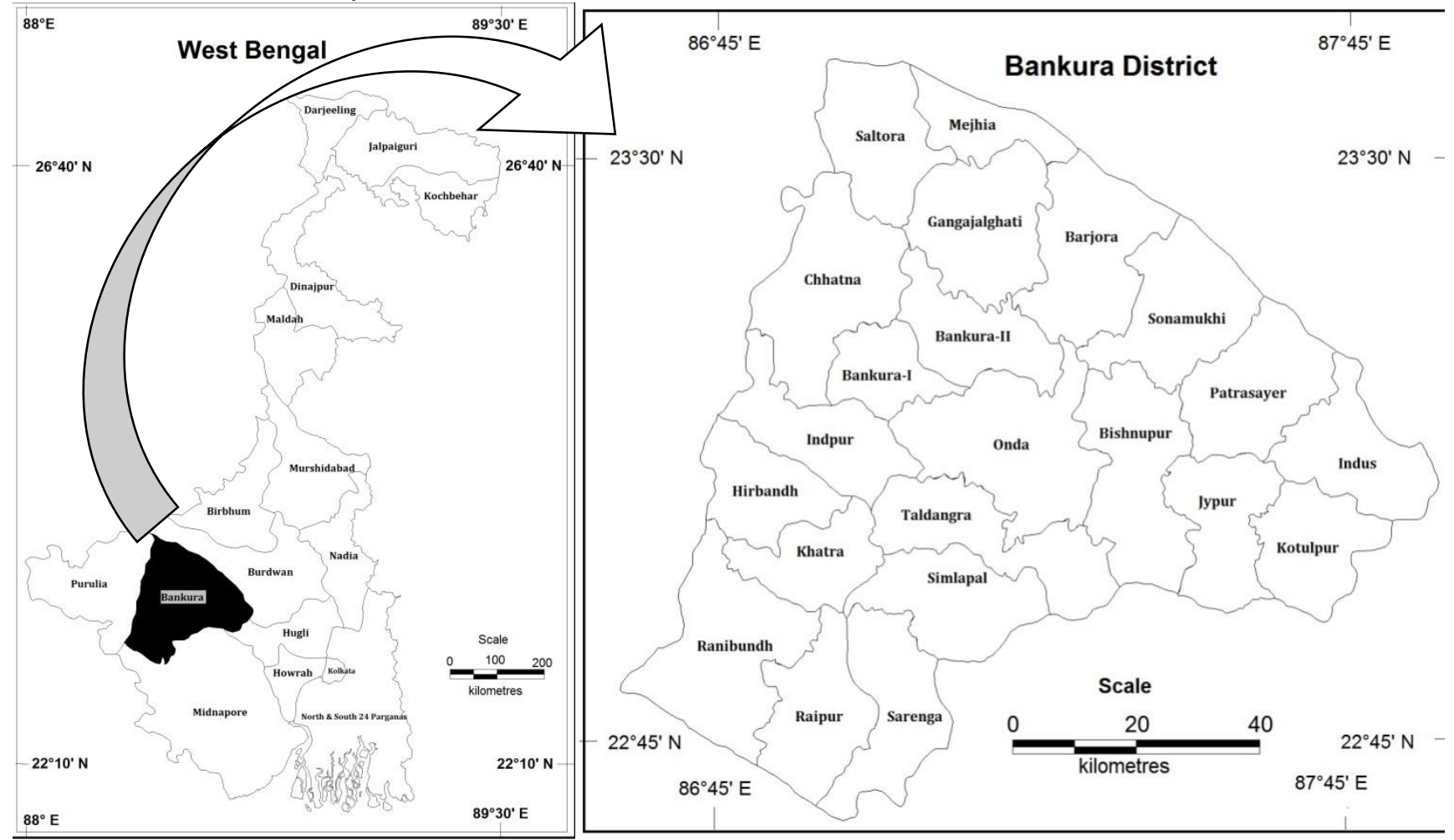

Figure 1: Location Map of Bankura District, West Bengal(Source: Prepared by Authors)

\section{Rationale: Bankura District as a Study Area}

Bankura ranks at $11^{\text {th }}$ among the 19 districts of West Bengal (H.D.R, 2006). In Bankura, Scheduled Castes (SCs) and Schedule Tribes
$(\mathrm{STs})^{1}$ are distributed all over the district. According to 2011 Census, the SCs account for

\footnotetext{
${ }^{1}$ Scheduled Castes (SC): The framers of the Constitution took note of the fact that certain castes, races or tribes in
} 
$32.65 \%$ of the total population. There is heavy concentration of SC population in the eastern part of the district, particularly in Sonamukhi, Indus, Patrasayer and Indpur. On the other hand, high concentrations of STs are found in western and southern part of the district. Bankura has 368,690 persons belonging to SC status. This accounts for $10.25 \%$ of the total population of the district. There is heavy concentration of STs in the districts of Ranibandh (47.07\%), Raipur (27.66\%), Khatra (22.2) and Sarenga (19.11\%). 11 out of 22 blocks in the district have been listed as educationally backward blocks (MHRD, 20072008). This reveals a contrasting picture of educational development among the blocks of the district. With regard to socio-economic conditions also, there are significant disparities among the blocks of the district. In the present work, an attempt has been made to investigate spatial patterns of educational development at primary level and illustrate the nature of disparity, which exists at the block levels in terms of ten important educational variablesPercentage of literate persons $\left(x_{1}\right)$, Gender gap in literacy $\left(x_{2}\right)$, Out of school children $\left(x_{3}\right)$, Pupilteacher ratio $\left(x_{4}\right)$, Dropouts in primary education $\left(x_{5}\right)$, Repetitions rate in primary

the country, who occupy the lowest rank in the ritual hierarchy of Indian society, were suffering from extreme social, educational and economic backwardness arising out of age-old practice of untouchability, lack of infrastructure facilities and geographical isolation, and who need special consideration for safeguarding their interests and for their accelerated socio-economic development. These communities were notified as Scheduled Castes (SC) as per provisions contained in Clause 1 of Articles 341 and 342 of the Constitution and have been defined under clause 24 of Article 366 of the Constitution of India. (National Commission for Schedule Castes, Govt. of India;

http://ncsc.nic.in/pages/view/73/68-introduction) Schedule Tribes (ST): The term first appeared in the Constitution of India. Article 366(25) defined schedule tribes as "such tribes or tribal communities or parts of or groups within such tribes or tribal communities as are deemed under Article 342 to be Schedule Tribes for the purposes of this constitution". Article 342, which is reported below, prescribes procedure to be followed in the matter of specification of schedule tribes. (Ministry of Tribal Affairs, Govt. of India; http://tribal.nic.in/Content/DefinitionpRrofiles.aspx) education $\left(\mathrm{x}_{6}\right)$, Primary schools without drinking water facilities $\left(x_{7}\right)$, Primary schools without toilet facilities $\left(\mathrm{x}_{8}\right)$, Enrolment of girl students in school $\left(x_{9}\right)$, Density of schools $\left(x_{10}\right)$.

\section{Objectives of the Study}

The key objective of the research is to examine the intra-district disparities in the levels of educational development in the Bankura district of West Bengal. In addition, the research also aims to examine the following: To assess the relative position of blocks in terms of level of educational development at the primary level.

To analyse the inter-relationships between the ten selected variables of education-Percentage of literate persons $\left(X_{1}\right)$, Gender gap in literacy $\left(X_{2}\right)$, Out of school children $\left(X_{3}\right)$, Pupil-teacher ratio $\left(X_{4}\right)$, Dropouts in primary education $\left(X_{5}\right)$, Repetitions rate in primary education $\left(X_{6}\right)$, Primary schools without drinking water facilities $\left(X_{7}\right)$, Primary schools without toilet facilities $\left(X_{8}\right)$, Enrolment of girl students in school $\left(X_{9}\right)$, Density of schools $\left(X_{10}\right)$ to understand to what extent these variables are related to each other.

\section{Database and Methodology}

The study is basically analytical in nature based on secondary data obtained from different sources such as District Census Handbook of Bankura district (2011) and various government publications-reports from Office of the District Project Officer, Sarva Siksha Abhiyan (SSA); District Information System for Education (DISE); Human Development Report of Bankura district (2007). The basic aim is to probe the spatial variations in the level of development of primary education in Bankura district. The work flows of measurement of regional disparities in education have been illustrated in Figure2. An in-depth study of educational development has been conducted by developing tools based on the following selected attributes:

- Percentage of literate persons $\left(X_{1}\right)$

- Gender gap in literacy $\left(X_{2}\right)$

- Out of school children $\left(X_{3}\right)$

- Pupil-teacher ratio $\left(X_{4}\right)$

- Dropouts in primary education $\left(X_{5}\right)$ 
- Repetitions rate in primary education $\left(X_{6}\right)$

- Primary schools without drinking water facilities $\left(X_{7}\right)$

- Primary schools without toilet facilities $\left(X_{8}\right)$

- Enrolment of girl students in school $\left(X_{9}\right)$

- Density of schools $\left(\mathrm{X}_{10}\right)$

To show the concentration of literacy rate in each block with respect to the whole district, Location Quotient (L.Q) has been used.

$$
L . Q=\frac{l}{t} / \frac{L}{T}
$$

Where,

L.Q = Location Quotient of literacy rate in a particular block.

I= literate persons in a block.

$\mathrm{t}=$ Total population in a block (excluding 0-6 years age group).

$\mathrm{L}=$ literate persons in the district.

$T=$ Total population in district (excluding 0-6 years age group).

L.Q depicts the relative concentration of an activity or work in block compared to the district. The value ranges between $<1$ to $>1$.

L.Q $>1=$ Indicates the block has greater concentration of literacy rate than the district.

L.Q 1 = Indicates that the literacy rate of the block is in accordance to the whole district.L. $Q<1=$ Indicates the block has lesser concentration of literacy rate than the district

As stated above, in order to assess the level of development of primary education, ten attributes were selected. The details about these attributes have also been mentioned earlier. Raw scores of each of these ten variables were standardised following the Zscore method. It is a linear transformation of the original data in such a way that its mean becomes zero and its standard deviation becomes unity. For observation ' $i$ ' of any variable, the Standard Score $\left(Z_{i}\right)$ is given by:

$Z_{i}=\left(X_{i}-\bar{X}\right) / \partial$

Where,

$X_{i}$ is the original value for observation (i)

$\overline{\mathrm{X}}$ is the mean for the variable and

$\partial$ is the Standard Deviation.

Z- Scores of each attribute was summated and mapped (using Maplnfo Professional software v.8.5) to examine the level of development in each block with regard to other blocks in Bankura district.

Apart from this, inter-relationships among the selected variables have been measured by Pearsonian Coefficient of Correlation (denoted by' $r$ '), considering other variables to be dependent on one independent variable at a time to understand how one specific variable controls other variables. It is a measure of the degree of association between two or more variables. The value of $r$ lies between -1 to +1 and cannot exceed 1 numerically. A positive value of $r$ indicates that high values of one variable are in general associated with high values of the other and low values are associated with corresponding low values of other variable. When $r$ is negative, high values of one variable are in general associated with low values of other. 


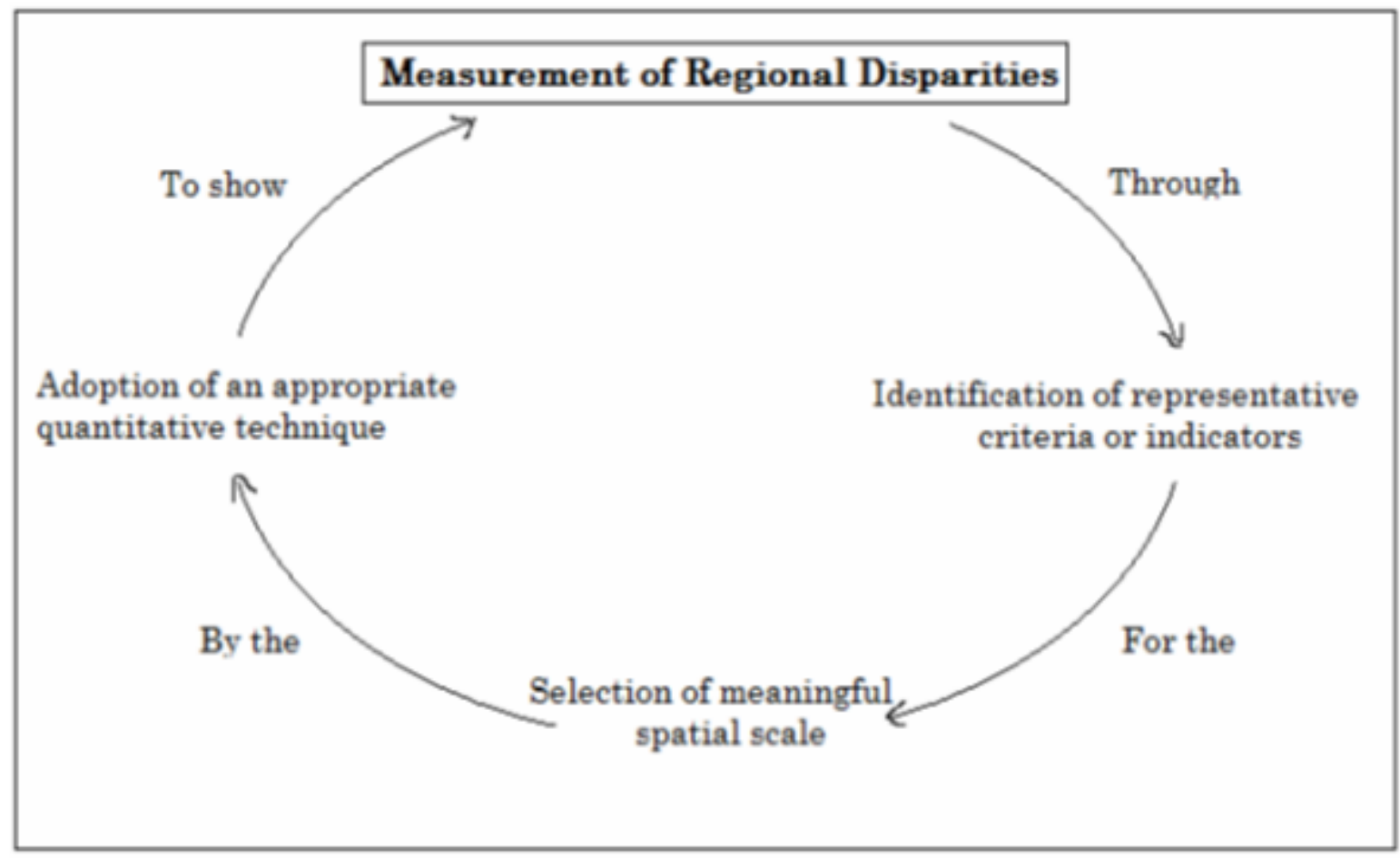

Figure 2: Measurement of Regional Disparities

Source: Adopted from Dubey, K.N. (1982)

Analysis and Discussion: Spatial Pattern of sporadic areas of low level of literacy (L.Q Selected Variables

\section{Literacy Status}

Literacy rate is considered as one of the crucial indictors of education. To measure the concentration of literate population, location quotient (L.Q) technique has been applied (see, Figure 3). Among 22 blocks, Kotulpur ranks 1st in the district with a literacy rate of $78.01 \%$ while Saltora is at the bottom with literacy rate of just $61.45 \%$. Analysis of the spatial data (Figure 3 ) reveals that the blocks of Jaypur, Kotulpur, BankuraII and Sarenga have high literacy rates (L.Q value 1.042 to 1.11 ) within the district, while blocks of Raipur, Khatra, Taldangra, Indus and Barjora belong to regions of moderately high literacy rate (0.984 to 1.042). A relatively large areas of central and western part of the district falls in the category of moderately low level of literacy (L.Q value 0.926 to 0.984 ) covering the blocks of Ranibandh, Indpur, Chhatna, Bankura-I, Gangajalghati, Mejhia, Onda, Bishnupur, Sonamukhi and Simlapal. There are also value 0.87 to 0.926 ) found in the blocks of Hirbandh, Saltora and Patrasayer. Economic backwardness and low participation of females in education in these areas contributes in the low level of literacy. Bankura district scores low in female literacy. While the male literacy rate is $80.05 \%$, the female literacy rate is just $60.05 \%$ resulting in a huge gender gap of 20 percent. High degree of gender gap in literacy rate is found in the blocks of the western part-Ranibandh, Hirbandh, Indpur and Saltoraregions (Census of India, 2011).

\section{Spatial Patterns of Availability of Educational Institutions}

Availability and location factors of schools are one of very fundamental requirements to any habitation. There are two types of institutions in the district-primary (up to $5^{\text {th }}$ grade) and Upper-Primary (up to $8^{\text {th }}$ grade). Apart from these, there are also non-formal education systems such as Shishu Shiksha Kendra (SSK), Madhyamik Shiksha Kendra (MSK) functioning in this 
district. The quality of learning in SSK and MSK is better than that in primary schools and upper primary schools. Generally, the Sahayika/Samprasaraks are from the same area and are committed and responsible to the community. The coverage of students by these non-formal systems is far less. An attempt has been made to probe the density

Bankura District Literacy Rate

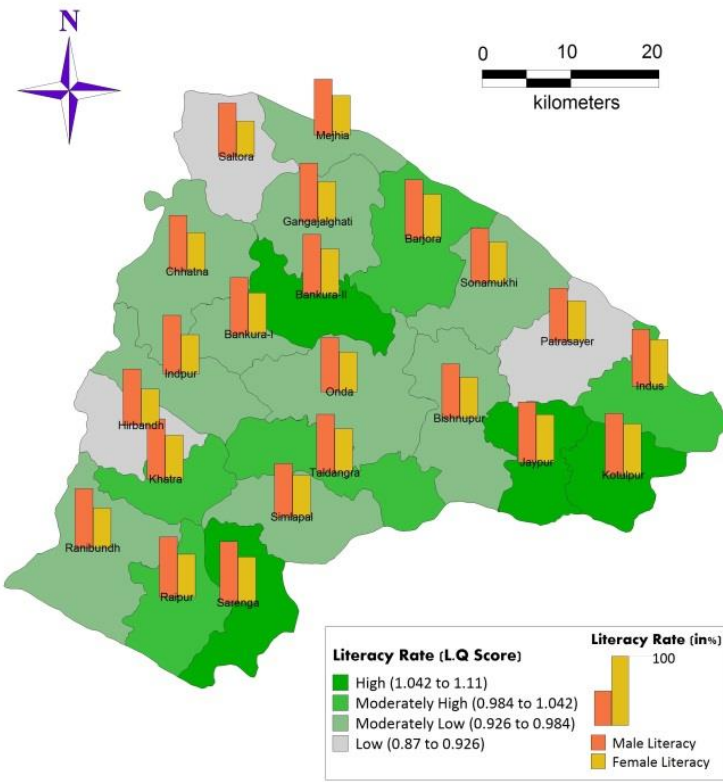

Figure 3: Literacy Rate

of schools on per 100,000population in each block. The less populous blocks in the southern part have moderately high (zscore0 to 1.02 ) to high (z-score 1.02 to 2 ) school density compared to the highly populous eastern part. Ranibandh, Simlapal, Taldangra and Chhatna have highest school density in the district (Figure 4).

Bankura District Density of Schools per Lakh Population

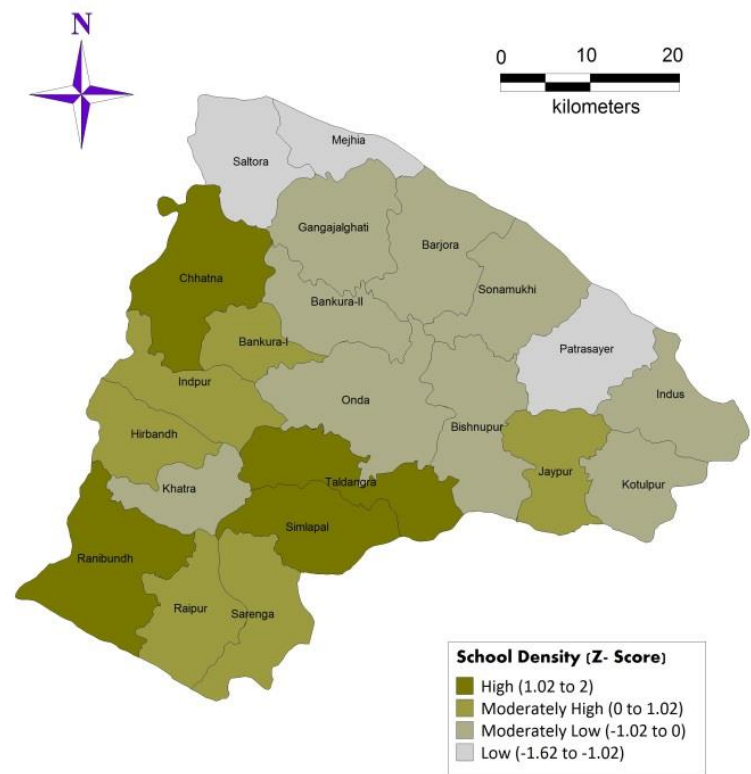

Figure 4: Density of Schools per Lakh Population

\section{Source: Computation and Mapping by Authors Based on Census of India, 2011}

\section{Pupil-Teacher Ratio}

Average number of pupils (students) per teacher at a specific level of education in a given school year (Education Indicators Technical guidelines, UNESCO).It is an important factor in imparting quality education. Though the overall pupil-teacher ratio in primary education in the district is 37.4 , it is seen that in many blocks, the ratio is much worse. A proper rationalisation of distribution of teachers is essential in order to bring the quality of learning to a reasonable level. It is clear from the map that the blocks of Gangajalghati, Indpur, Hirbandh, Mejhia, Patrasayer, Sonamukhi, Saltora and Simlapal have teacher pupil ratio of more than 40 pupils per teacher in primary level school. Kotulpur and Jaypur are in much better conditions when compared to the rest of the district with pupil-teacher ratio of 31.8 and 29.4 respectively in primary education. Like primary schools, there are also a large regional variations in the teacher-pupil ratio in upper-primary or middle schools throughout the district. The average pupilteacher ratio in secondary education is 44.03. It appears from Figure 5, that the blocks with very high teacher-pupil ratio in middle schools is few in number. Kotulpur, Jaypur, Mejhia, Patrasayer, Sarenga and Sonamukhi are in worsening conditions with more than 50 pupils per teacher. Kotulpur, Sarenga and Mejhia have highest pupilteacher ratio of $67.9,68$ and 71.9 
respectively. In case of higher-secondary schools, the overall pupil-teacher ratio is 42.81 but there are three blocks that have a pupil-teacher ratio of more than 50 students per teacher. These are Sarenga (50.2), Sonamukhi (54.2) and Bishnupur (51.6).

\section{Out of School Children}

Progress in literacy and education depends upon the propensity of children to go to school and to complete education at least up to the primary level. Enabling all children to obtain primary education is the key challenge particularly in some blocks in this district. Total out of school children in this

Bankura District

Pupil - Teacher Ratio

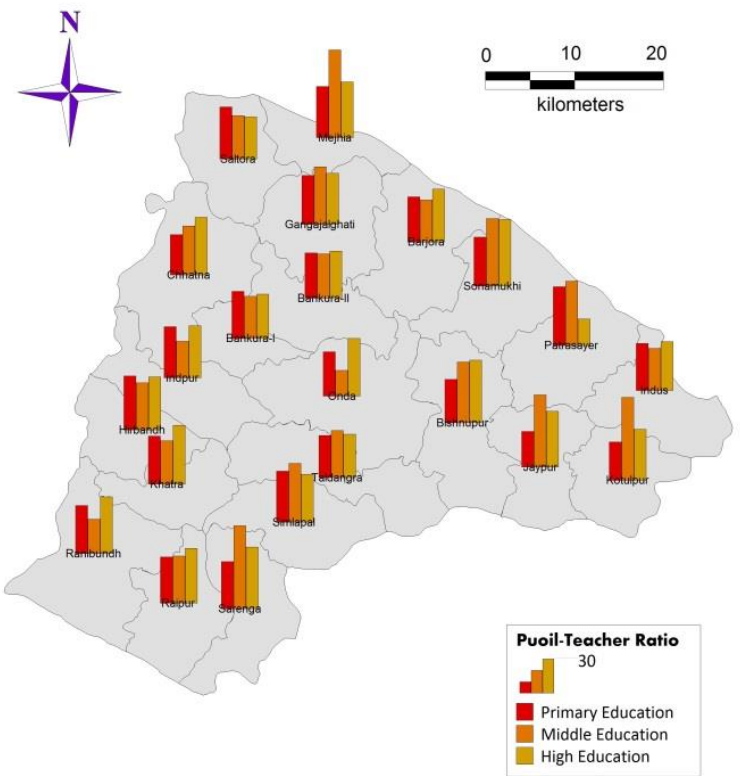

Figure 5: Pupil-Teacher Ratio district for primary segment (aged $5+$ to 9years) are17370 and for upper primary (aged $9+$ to 14 years) it is 31564.In the blocks like Gangajalghati, Patrasayer, Saltora, Mejhia, Bankura-I the percentage of out of school children of the total population of children (aged $5+$ to 8 years) group are 10.21, 7.31, 11.17, 6.08, and 6.70 respectively (Figure 6 ). These are the blocks where percentage of out of school children is relatively higher. Lack of access to school for large number of children and infrastructural backwardness are the major bottlenecks in western and north-western parts of the district (Figure 7).

\section{Bankura District}

Out of School Children

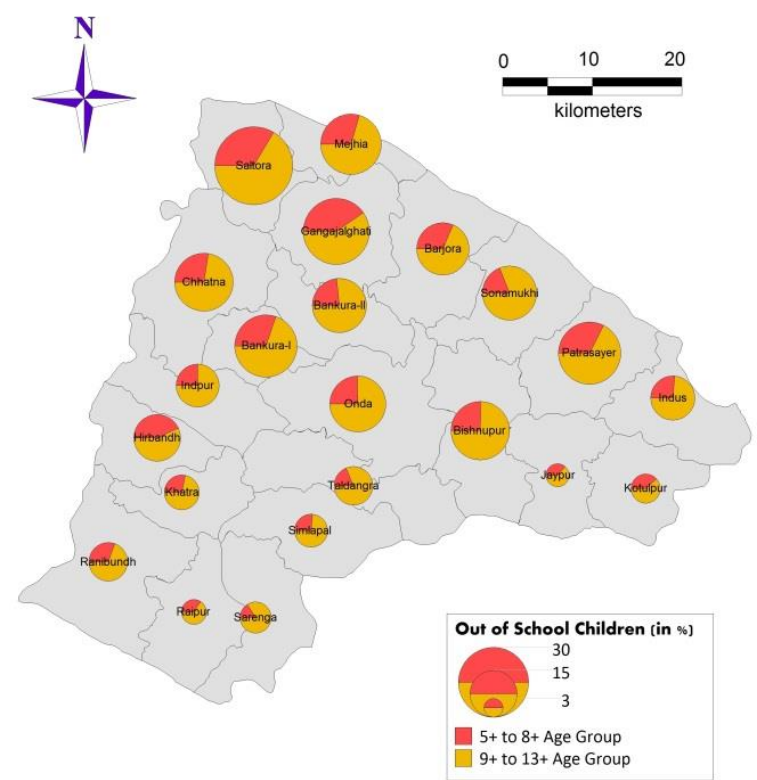

Figure 6: Out of School Children

Source: Prepared by Authors Based on Bankura District Human Development Report, 2007 


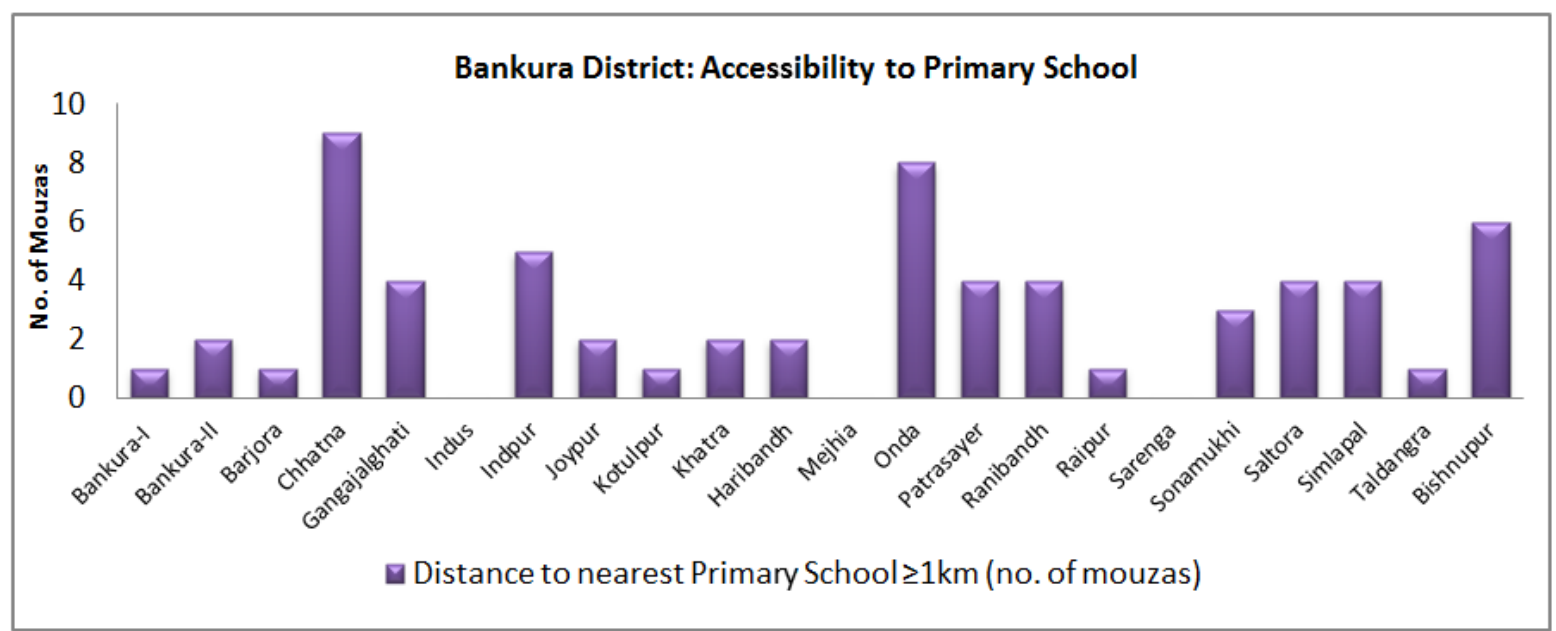

Figure 7: Accessibility to Primary Schools

Source: Prepared by Authors Based on Bankura District Human Development Report, 2007

Drop-Outs and Repeaters in Primary Boro and Kharif seasons. ${ }^{2}$ Hence, children Education are compelled to migrate with their families

Drop-outs can be defined as proportion of pupils from a cohort enrolled in a given grade at a given school year that is no longer enrolled in the following school year. On the other hand, repeaters can be defined as proportion of pupils from a cohort enrolled in a given grade at a given school year who studies in the same grade in the following school year (Education Indicators Technical guidelines, UNESCO). As can be seen from Figure 8 , the dropout is the maximum $(-1.93$ to -1.02$)$ in the Indus, Taldangra, Bankura-I and Mejhia. It is highest in Indus (17\%) followed by, Taldangra (16\%) and Bankura-I (14\%). Chhatna, Bankura-II, Barjora, Sarenga, Simlapal and Bishnupur have moderately high (-1.02 to 0) dropout rates. Indpur, Khatra, Hirbandh and Saltora have low (1.02 to 1.5) dropout rates compared to other blocks. Seasonal migration is one of the major causes of drop-out and out-ofschool for children in some areas of this district (Human Development Report of Bankura district, 2007). Families from Bankura-I, Chhatna, Indpur, Khatra, Ranibandh, Simlapal blocks migrate to the eastern district as agricultural labours in and therefore, they remain detached from studies and schools. These findings bear resonance with that of research findings of Roy et al., (2015). Similarly, the percentage of repeaters is highest (-2.46 to -1.03$)$ for Simlapal (51\%) followed by Raipur (44\%), Sarenga (39\%) and Ranibandh (34\%). Saltora, which has the highest percentage of out of school children registers very low (1.02 to 1.43) repetition rates. Moderately high (-1.03 to0) repetition rates are found in Khatra, Taldangra, Onda, Bankura-II, Sonamukhi and Patrasayer. Rest of the blocks in the district have moderately low (0 to 1.02 ) repetition rates (Figure 9).The problem of dropout and repetitions are linked closely to the quality of education.

\footnotetext{
${ }^{2}$ Kharif crops are usually sown with the beginning of the first rains in July, during the south-west monsoon season. (Crop Calendar of major crops, Directorate of Economics and Statistics, Ministry of Agriculture, Government of India, retrieved from http://eands.dacnet.nic.in/At_A_Glance-

2011/Appendix-IV.xIs) The Boro rice is commonly known as winter rice. The term boro is Bengali originated from the Sanskrit word "Boro" which refers to a cultivation from Nov.-May under irrigated condition. (International Rice Research Institute (IRRI), retrieved from, http://www.narc.gov.np/rice_knowledge_bank/facts heet/boro.pdf)
} 
Poor quality schooling reduces completion rates. Even for upper primary levels, the dropout rates in class $\mathrm{V}$ are highest. The

\section{Bankura District}

Dropouts in Primary Education

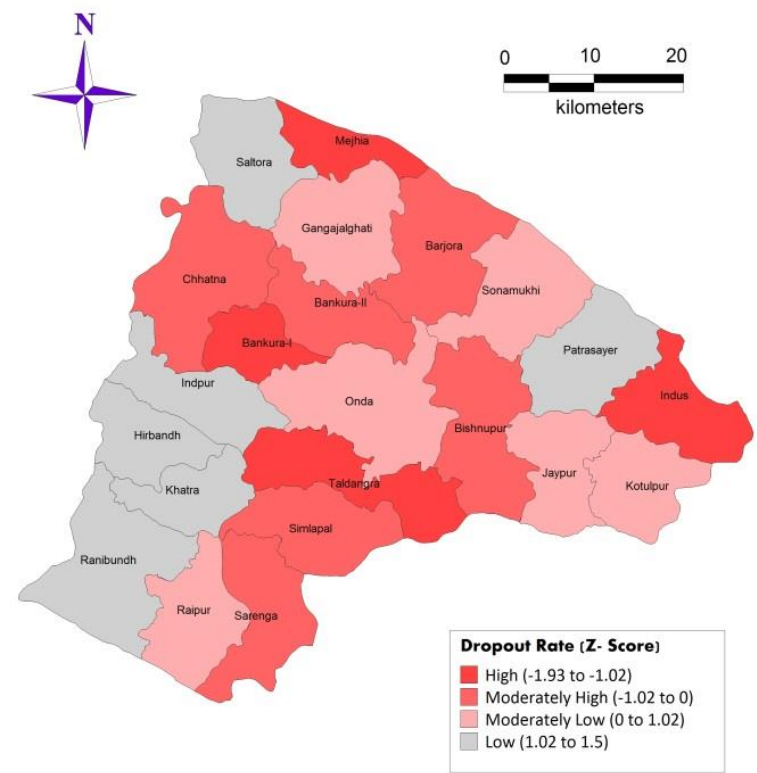

Figure 8: Dropouts in Primary Education main reason for this is the very poor level of learning of Class IV children.

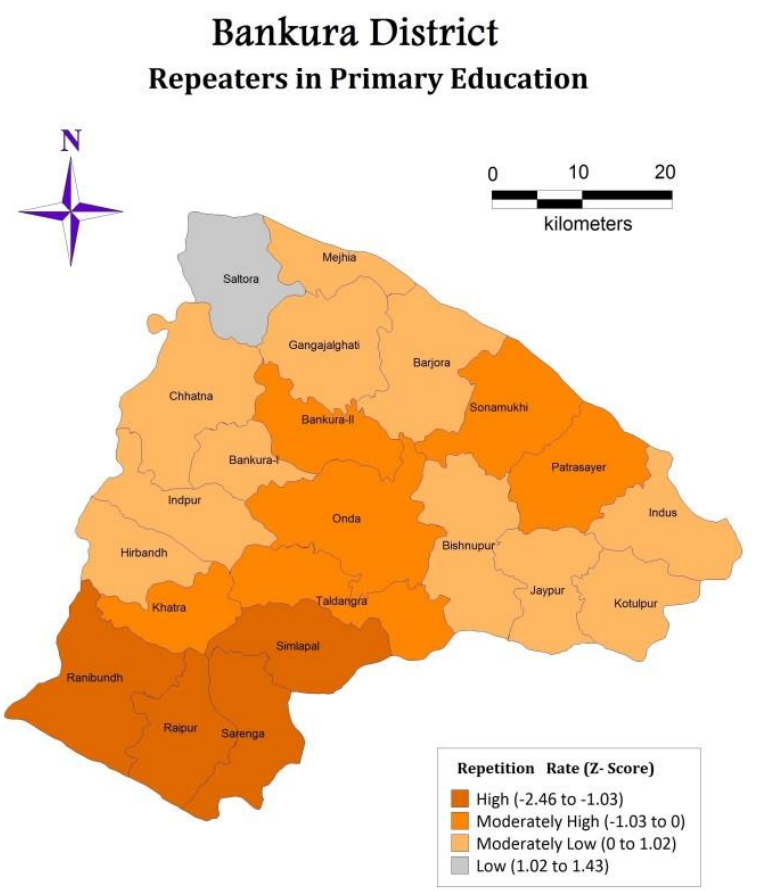

Figure 9: Repeaters in Primary Education Source: Prepared by Authors Based on Bankura District Human Development Report, 2007 Drinking Water and Sanitation Facilities in Primary Schools

Infrastructure related factors play an important role in motivating girls to enrol and stay in schools. Other important factors are toilets and drinking water facilities in schools. Most of the blocks in the western and north-western parts of the district have comparatively high (21.6 to 27.8) percentages of schools without drinking water facilities. These are Barjora, Saltora, Indpur, Hirbandh, Taldangra and Raipur. Moderately high (14.1 to 21.6) percentages of primary schools in Gangajalghati and Chhatna are running without any facilities of drinking water. Kotulpur, Jaypur, Patrasayer and Sarenga are in better conditions having low (1.8 to 6.6) percentages of schools without drinking water facilities. Rest of the blocks in the district have moderately low (6.6 to 14.1) percentages of schools without the facilities of drinking water (Figure 10). Sanitation is one of the basic requirements for children in school. Problem of sanitation is a major reason for non-attendance of the girls in primary schools. This is one of the key barriers for the girls in primary schools. Indus, Jaypur, Kotulpur, Bishnupur and Bankura-I have relatively better toilet facilities. There are low (7.8 to 26.6) percentages of schools without toilet facilities in these blocks (Figure 11). Patrasayer, Sonamukhi, Khatra, Ranibandh have 26.6 to $50 \%$ schools without toilet facilities. A large number of blocks in the district have moderately high (50 to 73.5) percentages of schools without any toilet facilities.

\section{Space-Student Ratio in Primary Schools}

Class room infrastructure is definitely a very important issue. The national norm is to provide 10 square feet for each child. As per the District Information System for Education (DISE) 2007 data, there are 2188 primary schools in this district where spacestudent ratio is less than 7 square feet. All 
the schools have been indexed as per the space-student ratio in this district and the schools bearing the worst ratio are being given priority for additional classrooms under the SSA. Figure 12shows block wise number of primary schools where the spacestudent ratio is less than $7 \mathrm{sq}$. $\mathrm{ft}$. There are large numbers (63.1\% to $68.2 \%$ ) of schools in Kotulpur, Sonamukhi, Bankura-II and Sarenga, which are with less than 7 sq. feet space per student. Most of these blocks are highly populous and have low school density. This is a major factor that can be

\section{Bankura District}

Availability of Drinking Water in Primary Schools

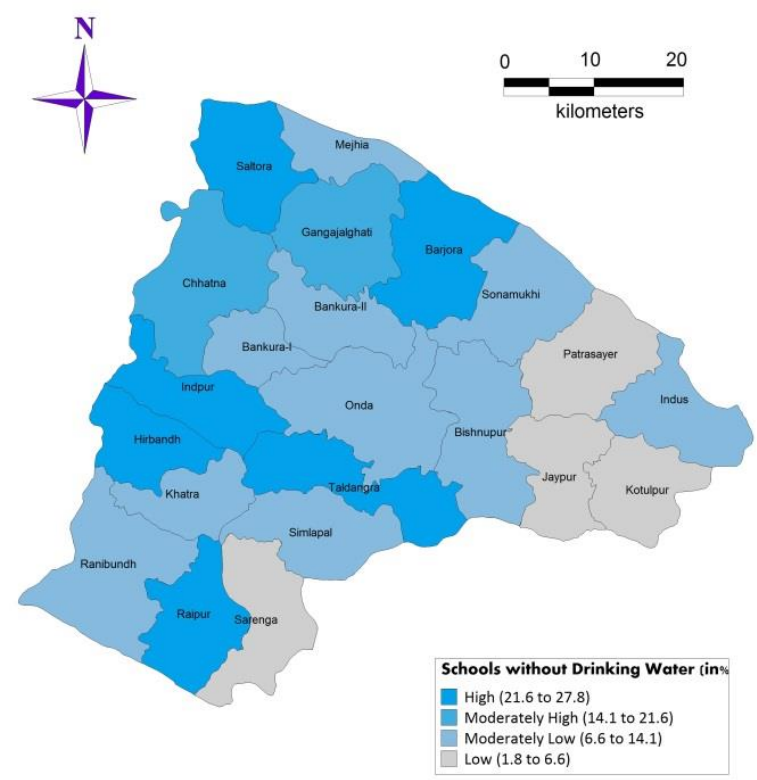

Figure 10: Drinking Water Facility in Primary School the probable reason behind this. In Municipal areas, there are large numbers of primary schools, which suffer from space problem. A serious negotiation with the community therefore remains paramount so that private land could be obtained for setting up of the required spaces for schools. In extreme cases, where other options of expansion through negotiations with community are not possible, land acquisition with the help of administration can be the only answer.

\section{Bankura District}

Availability of Sanitation Facility in Primary Schools

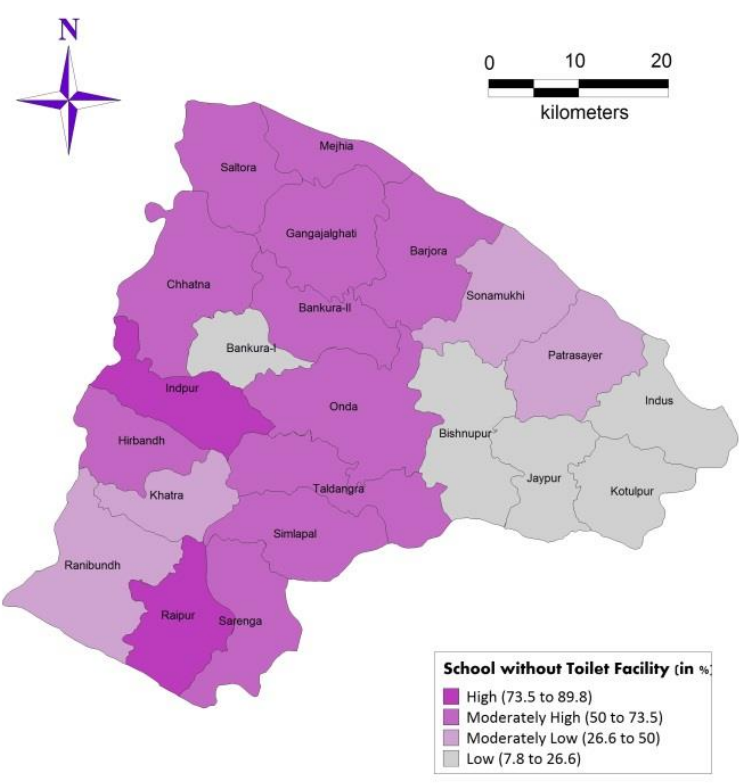

Figure 11: Sanitation Facility in Primary School

Source: Prepared by Authors Based on Bankura District DISE Report, 2007 
Bankura District

Space-Student Ratio in Primary \& Upper Primary Schools

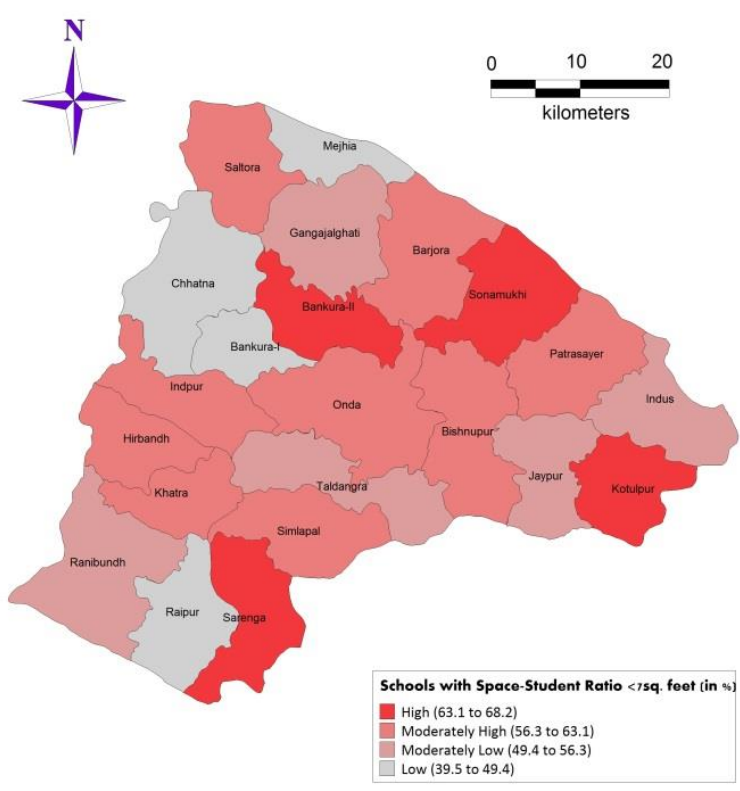

Figure 12: Space-Student Ratio in Schools

Source: Prepared by authors based on Bankura District DISE Report, 2007

\section{Inter-relationships between Selected Variables of Education}

In this section, an attempt has been made to analyse the inter-relationships among the selected variables; considering other variables to be dependent on one independent variable at a time to understand how one specific variable controls other variables. As can be observed from the " $r$ " values computed for all the ten variables of education in Bankura district, six variables (such as gender gap in literacy, pupil-teacher ratio, dropout rates, drinking water facilities in school, sex ratio of enrolment and school density) have a reciprocal and positive correlation with overall literacy rates.

Five variables are strongly correlated to gender gap in literacy rates. Better sanitation facilities in school motivate girls to enrol and stay in schools. Enrolment ratio of girls in school and drop-out rate is negatively correlated; this means the more the enrolment of girls, the less are the dropout rates. It clearly indicates that drop-out rates are gender selective in nature.
Repeaters rates and out of school children are negatively correlated. This is interesting because this means the less the percentage of out-of-school children, the more repeaters in school (Table-1).

\section{Spatial Patterns of Integrated Educational Development}

Analysis of various attributes of education sector reveals that the spatial patterns of development are not uniform throughout the area under study. The study shows contrasting picture of development from one block to the other (Table-2). Keeping these facts in mind, an attempt has been made to assess the relative position of blocks in terms of level of educational development taking into account ten basic indicators (mentioned in earlier section). The entire data of composite scores are again divided into high, moderately high, moderately low and low categories. A very high level of education is represented by the composite z-scores of 4.8 to 11.6, moderately high level ranges from 0.1 to 4.8, moderately low level ranges from -4.7 to 0.1 and low level of educational 
development is represented by z-scores of 8.7 to -4.7. Therefore, from the foregoing analyses based on ten basic attributes of education, the whole district can be categorised into four developmental zones and thus, proper strategies can be taken by identifying the weak segment of a particular block (Table-3). For Saltora, Gangajalghati and Hirbandh (Range -8.7 to -4.7 ), almost all ten indicators are on negative side for all these blocks. There is high level of gender disparity. These blocks are also lacking in infrastructural development; both sanitation and drinking water facilities needs to be improved a lot. Only school density in Chhatna block seems to be a lone positive out of all ten indicators. While Kotulpur and Jaypur scores 11.56 and 10.21 respectively on-integrated index of educational development and out of the ten indicators, nine seems to be more or less on higher side in both of these blocks. Only one attribute, that is, school density is relatively on the lower side for Kotulpur block.

\begin{tabular}{|c|c|c|c|c|c|c|c|c|c|c|}
\hline \multicolumn{11}{|c|}{ Table 1: Correlation Coefficients $(r)$ among variables of Education in Bankura District } \\
\hline \multirow[b]{2}{*}{$\begin{array}{l}\text { Variables of } \\
\text { Education }\end{array}$} & $\mathrm{x}_{1}$ & $x_{2}$ & $x_{3}$ & $x_{4}$ & $\mathrm{x} 5$ & x6 & $x 7$ & $x_{8}$ & $\mathrm{xg}$ & $\mathrm{x} 10$ \\
\hline & Overall literacy & $\begin{array}{l}\text { GenderGap } \\
\text { in Literacy }\end{array}$ & $\begin{array}{c}\text { Out of School } \\
\text { Children (5+ to } 8+ \\
\text { age group) }\end{array}$ & \begin{tabular}{|c|}
$\begin{array}{c}\text { Pupi--Teacher } \\
\text { Ratio at Primary } \\
\text { Level }\end{array}$ \\
\end{tabular} & $\begin{array}{l}\text { Drop Outs at } \\
\text { Primary Level }\end{array}$ & $\begin{array}{l}\text { Repe aters at } \\
\text { primary level }\end{array}$ & $\begin{array}{l}\text { Primary schools } \\
\text { without drinking } \\
\text { water faolity }\end{array}$ & \begin{tabular}{|c|}
$\begin{array}{c}\text { Primary schools } \\
\text { without toilet } \\
\text { fadility }\end{array}$ \\
\end{tabular} & $\begin{array}{l}\text { ser ratio of } \\
\text { enrolment }\end{array}$ & School Density \\
\hline $\mathrm{x} 1$ & 1 & 0.99 & 0.295 & 0.991 & 0.998 & 0.183 & 0.99 & 0.381 & 0.573 & 0.923 \\
\hline $\mathrm{x} 2_{2}$ & & 1 & 0.292 & 0.994 & 0.994 & 0.178 & 0.996 & 0.642 & 0.501 & 0.881 \\
\hline $\mathrm{x}_{3}$ & & & 1 & 0.297 & 0.279 & $\cdot 0.478$ & 0.292 & 0.12 & 0.603 & 0.248 \\
\hline $\mathrm{x}_{4}$ & & & & 1 & 0.993 & 0.185 & 0.998 & 0.356 & 0.181 & 0.885 \\
\hline $\mathrm{x} 5$ & & & & & 1 & 0.189 & 0.994 & -0.217 & -0.442 & 0.914 \\
\hline$x_{6}$ & & & & & & 1 & 0.178 & 0.286 & -0.406 & 0.189 \\
\hline$x 7$ & & & & & & & 1 & 0.651 & 0.268 & 0.884 \\
\hline$x_{8}$ & & & & & & & & 1 & 0.286 & -0.316 \\
\hline$x 9$ & & & & & & & & & 1 & 0.266 \\
\hline \multirow[t]{2}{*}{$\mathrm{X} 10$} & & & & & & & & & & 1 \\
\hline & $\begin{array}{l}\text { Co-relatic } \\
\text { Co-relati }\end{array}$ & $\frac{n \text { is significan }}{n \text { is significan }}$ & tit at the $0.01 \mathrm{level}(\mathrm{a})$ & $\frac{(2 \text { tailed })}{(2 \text { tailed })}$ & \multicolumn{6}{|c|}{ Source: Computed by Author } \\
\hline
\end{tabular}

Note: raw values of all ten variables have been standardised following z-score method and signs have been altered for those variables that have reverse impact on composite scores. Correlation coefficients " $r$ " values have been obtained on the basis of $z$-scores of all the variables.

\begin{tabular}{|c|c|c|c|c|c|c|c|c|c|c|c|c|c|c|c|c|c|c|c|c|c|}
\hline \multicolumn{22}{|c|}{ Table 2: Work Sheet for Composite Index of Educational Development in Bankura District } \\
\hline SI. No. & Block & Overall literacy & Z-Score & $\begin{array}{c}\text { Gender Gap in } \\
\text { literacy }\end{array}$ & $\begin{array}{l}\text { Z. Score } \\
\text { (opposite } \\
\text { direction) }\end{array}$ & $\begin{array}{c}\text { \%of Out of f school } \\
\text { Childeren (5+ to } 8+ \\
\text { age group) }\end{array}$ & \begin{tabular}{c|c} 
7.Score \\
(opositederiction)
\end{tabular} & $\begin{array}{c}\begin{array}{c}\text { Pupil-Teacher } \\
\text { Ratio at Primary } \\
\text { Level }\end{array} \\
\text { Let }\end{array}$ & 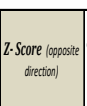 & 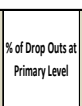 & $\begin{array}{l}\text { Z.S Score } \\
\text { (opposite } \\
\text { direction) }\end{array}$ & $\begin{array}{c}\text { Yoof Reperters at } \\
\text { pimarylevel }\end{array}$ & $\begin{array}{l}\text { Z-Score } \\
\text { (opposite } \\
\text { direction) }\end{array}$ & \begin{tabular}{|c|}
$\begin{array}{c}\text { Primary shools } \\
\text { without drinking } \\
\text { water falihy (in } \\
\text { \%) }\end{array}$ \\
\end{tabular} & $\begin{array}{l}\text { Z-Score } \\
\text { (opposite } \\
\text { direction) }\end{array}$ & \begin{tabular}{|l|} 
Primary schools \\
without toliet \\
facility (ing)
\end{tabular} & $\begin{array}{l}\text { Z-Score } \\
\text { lopposite } \\
\text { direction) }\end{array}$ & $\begin{array}{c}\text { Sex ratio } \\
\text { of } \\
\text { enrolme } \\
\text { nt (Girls }\end{array}$ & Z-Score & 2-Score & $\begin{array}{l}\text { Compositite. } \\
\text { Score Values } \\
\text { (Etuctiononal } \\
\text { Index) }\end{array}$ \\
\hline 1 & Bankura-L & 68.74 & .0 .1 & 21.25 & $\cdot 0.06$ & 6.7 & -0.87 & 38.7 & .0 .02 & 14 & .129 & 14 & 0.36 & 13.46 & 0.09 & 18.27 & 1.38 & 997 & 1.61 & 0.12 & 1.22 \\
\hline 2 & Bankura-II & 73.59 & 1.14 & 19.76 & 0.37 & 4.1 & 0.11 & 36.8 & 0.44 & 11 & .0 .64 & 20 & -0.09 & 10.66 & 0.46 & 58.2 & .0 .36 & 918 & 0.41 & -0.97 & 0.05 \\
\hline 3 & Barjora & 71.67 & 0.65 & 19.2 & 0.53 & 5.27 & .0 .33 & 36.9 & 0.41 & 9 & .0 .21 & 8 & 0.82 & 22.63 & -1.16 & 53.68 & $\cdot 0.16$ & 941 & 0.18 & 0.68 & 0.05 \\
\hline 4 & Chhatna & 65.73 & $\cdot 0.87$ & 24.3 & .0 .93 & 5.31 & $\cdot 0.35$ & 33.5 & 1.24 & 10 & .0 .43 & 11 & 0.59 & 18.83 & -0.64 & 66.95 & .0 .74 & 879 & -1.41 & 1.09 & 2.45 \\
\hline 5 & Gangajalghati & 68.11 & .0 .26 & 24.04 & .0 .86 & 10.21 & .22 & 40 & .0 .34 & 5 & 0.64 & 9 & 0.74 & 19.75 & -0.77 & 62.35 & .0 .54 & 864 & -1.79 & 0.76 & 6.14 \\
\hline 6 & Indus & 71.76 & 0.67 & 14.73 & 1.8 & 3.41 & 0.37 & 38.4 & 0.05 & 17 & .1 .93 & 10 & 0.67 & 9.92 & 0.57 & 7.8 & 1.84 & 982 & 1.23 & -1 & 4.27 \\
\hline 7 & Indpur & 67.42 & .0 .44 & 25.62 & .131 & 2.92 & 0.55 & 42.1 & .0 .85 & 3 & 1.07 & 12 & 0.51 & 22.89 & -1.19 & 89.76 & -1.73 & 949 & 0.38 & 0.5 & 2.51 \\
\hline 8 & loypur & 74.57 & 1.39 & 17.3 & 1.07 & 1.43 & 1.12 & 29.4 & 2.23 & 6 & 0.43 & 12 & 0.51 & 6.37 & 1.05 & 21.66 & 1.24 & 956 & 0.56 & 0.61 & 10.21 \\
\hline 9 & Kotulpur & 78.01 & 2.27 & 14.3 & 1.93 & 2.39 & 0.75 & 31.8 & 1.65 & 4 & 0.86 & 10 & 0.67 & 1.89 & 1.65 & 10.69 & 1.72 & 973 & 1 & 0.94 & 11.56 \\
\hline 10 & Khatra & 72.18 & 0.78 & 23.1 & .0 .59 & 2.42 & 0.74 & 39.5 & .0 .22 & 3 & 1.07 & 26 & -0.55 & 12.07 & 0.27 & 37.07 & 0.57 & 899 & -0.9 & 0.17 & 1 \\
\hline 11 & Haribandh & 64.18 & $\cdot-1.27$ & 27.94 & -1.97 & 5.64 & .0 .47 & 44.4 & -1.4 & 1 & 1.5 & 7 & 0.89 & 27.78 & -1.86 & 66.67 & .0 .72 & 900 & 0.087 & 0.58 & .5 .59 \\
\hline 12 & Mejhia & 66.83 & .0 .59 & 22.9 & .0 .53 & 6.08 & .0 .64 & 42.2 & -0.87 & 13 & $\begin{array}{l}1.07 \\
\end{array}$ & 7 & 0.89 & 8.33 & 0.78 & 55.56 & .0 .24 & 914 & .0 .51 & -1.62 & 4.33 \\
\hline 13 & Onda & 65.82 & $\cdot 0.85$ & 19.63 & 0.4 & 4.53 & .0 .05 & 36.6 & 0.49 & 7 & 0.21 & 22 & .0 .25 & 13.17 & 0.12 & 63.79 & .0 .6 & 883 & -1.31 & 0.38 & 2.22 \\
\hline 14 & Patrasayer & 64.87 & -1.1 & 17.46 & 1.02 & 7.31 & .1 .1 & 47.9 & .225 & 3 & 1.07 & 26 & .0 .55 & 5.71 & 1.14 & 45 & 0.22 & 940 & 0.15 & -1.37 & 2.77 \\
\hline 15 & Ranibandh & 68.53 & $\cdot 0.15$ & 25.28 & .121 & 3.08 & 0.49 & 39.5 & .0 .22 & 3 & 1.07 & 34 & .1 .16 & 12.9 & 0.16 & 42.58 & 0.33 & 931 & .0 .08 & 2 & 1.23 \\
\hline 16 & Raipur & 71.33 & 0.56 & 22.79 & .0 .5 & 1.62 & 1.05 & 38 & 0.15 & 7 & 0.21 & 44 & .1 .92 & 22.8 & -1.18 & 81.87 & $\cdot-1.39$ & 977 & 1.1 & 0.94 & 0.98 \\
\hline 17 & Sarenga & 74.25 & 1.31 & 21.01 & 0.01 & 1.04 & 1.26 & 38.6 & 0.002 & 11 & .0 .64 & 39 & .1 .54 & 6.14 & 1.08 & 53.51 & -0.15 & 983 & 1.26 & 0.95 & 3.54 \\
\hline 18 & Sonamukhi & 66.16 & .0 .76 & 18.68 & 0.67 & 3.35 & 0.39 & 40.5 & .0 .46 & 7 & 0.21 & 19 & -0.02 & 7.19 & 0.93 & 39.87 & 0.44 & 941 & 0.18 & .0 .3 & 1.28 \\
\hline 19 & Saltora & 61.45 & -1.96 & 25.38 & -1.24 & 11.17 & .256 & 42.6 & 0.097 & 2 & 1.29 & 0 & 1.43 & 23.53 & -1.28 & 68.07 & -0.79 & 874 & -1.54 & -1.05 & 8.67 \\
\hline 20 & Simlapal & 68.44 & 0.18 & 20.27 & 0.22 & 1.87 & 0.95 & 42.1 & -0.85 & 12 & .0 .86 & 51 & .245 & 8.77 & 0.72 & 72.51 & .098 & 959 & 0.64 & 1.6 & -1.19 \\
\hline 21 & Taldangra & 70.87 & 0.45 & 19.21 & 0.52 & 1.78 & 0.98 & 34.4 & 1.02 & 16 & $\cdot 1.72$ & 26 & .0 .55 & 25.61 & -1.56 & 70.12 & .0 .88 & 980 & 1.18 & 1.26 & 1.8 \\
\hline \multirow[t]{2}{*}{22} & Bishnupur & 66.3 & $\cdot .72$ & 18.82 & 0.63 & 4.99 & 0.23 & 35.5 & 0.75 & 12 & .0 .86 & 6 & 0.97 & 9.52 & 0.62 & 14.97 & 1.53 & & -0.67 & 0.42 & 2.06 \\
\hline & & \multicolumn{2}{|c|}{ 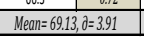 } & \multicolumn{2}{|c|}{ Mean=21.04, $\partial=3.50$} & \multicolumn{2}{|c|}{$\frac{1.53}{\text { Mean }=4.39,0=2.65}$} & \multicolumn{2}{|c|}{ Mean $=38.61,0=4.13$} & \multicolumn{2}{|c|}{ Mean $=8.00, \partial=4.66$} & \multicolumn{2}{|c|}{\begin{tabular}{|c|} 
Mean $=18.77,0=13.17$ \\
\end{tabular}} & \multicolumn{2}{|c|}{\begin{tabular}{ll|} 
Mean $=14.09,0=7.38$ \\
\end{tabular}} & \multicolumn{2}{|c|}{\begin{tabular}{c|c|}
11.97 & I 1.35 \\
Mean $=50.04,0=22.94$
\end{tabular}} & \multicolumn{2}{|c|}{ Mean $=934,0=39.01$} & & \\
\hline & & & & & & & & & & omput & by Au & & & & & & & & & & \\
\hline
\end{tabular}




\section{Bankura District}

Level of Integrated Educational Development

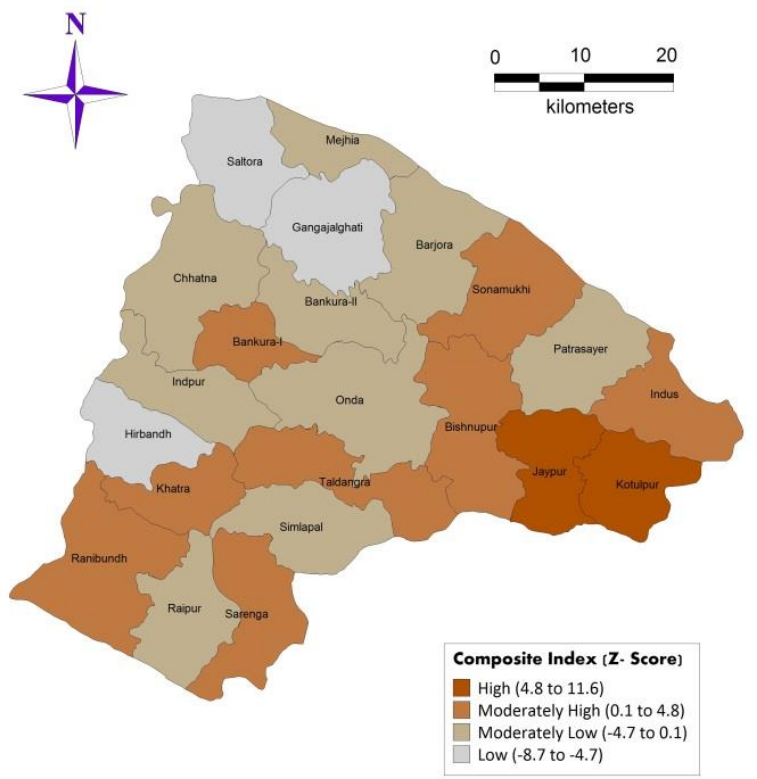

Figure 13: Level of Integrated Educational Development

Source: Computation and Mapping by Authors Based on Bankura District Human Development Report 2007, DISE Report, 2007 \& Census of India, 2011

\begin{tabular}{|l|c|c|l|}
\hline \multicolumn{4}{|c}{ Table3: Level of Integrated Educational Development in Bankura District } \\
\hline Category & Range & $\begin{array}{c}\text { No. of } \\
\text { Blocks }\end{array}$ & \multicolumn{1}{c|}{ Name of Blocks } \\
\hline High & 4.8 to 11.6 & 2 & Kotulpur and Jaypur \\
\hline Moderate & 0.1 to 4.8 & 8 & $\begin{array}{l}\text { Sarenga, Taldangra, Indus, Sonamukhi, } \\
\text { Bishnupur, Bankura-I, Khatra and Ranibandh }\end{array}$ \\
\hline Low & -4.7 to 0.1 & 9 & $\begin{array}{l}\text { Raipur, Chhatna, Barjora, Mejhia, Bankura-II, } \\
\text { Simlapal, Indpur, Onda and Patrasayer }\end{array}$ \\
\hline Very Low & -8.7 to -4.7 & 3 & Saltora, Gangajalghati and Hirbandh \\
\hline
\end{tabular}

\section{Conclusion}

Analyses of the selected variables reveal that substantial regional variation exists in the level of development of education throughout the district of Bankura. All the indicators of education shows regional disparities at block levels which is compounded into overall disparity in education in the study area (Table-3, Figure 13).From the present analysis, it can be identified that most of the blocks in north- western part are trailing behind others. Basic school amenities like sanitation and drinking water facilities within school premises need to be improved. Pupilteacher ratio in primary and upper-primary levels must be improved to match the RTE act recommendations (that is, pupil-teacher ratio of 30:1 for primary levels and 35:1 for upper-primary levels). In conclusion, it can be said that Bankura district is educationally unsound district with substantial regional 
disparities in the levels of educational development.

\section{References}

Aggarwal, J. C. (2004): Teacher and Education in a Developing Society. New Delhi: Vikash Publication House, pp. 9.

Ahmad, A. (1982). Inter-Regional Inequalities in Literacy Levels of Tribal and the Caste Segment of Population in India. 1971, Paper presented at regional workshop in Long-Term Educational Planning, NIEPA. New Delhi.

Ahamad, H. (2008). Regional Disparities in the Levels of Education in Uttar Pradesh, PhD thesis, Aligarh Muslim University, Aligarh.

Bhattacharyya, Rituparna (2009). Examining the Changing Status and Role of Middle Class Assamese Women: Lessons from the Lives of University Students, PhD thesis, Newcastle University, UK

Barooah, Momita (2014). Spatial Pattern and Variation in Literacy Among the Scheduled Castes Population in the Brahmaputra Valley, Assam, Space and Culture, India, 2(1), 24-32, DOI: http://dx.doi.org/10.20896/saci.v2i1.68

Chowdhry, S. \&Burgohain, T. (1993). Educational Status: A Case Study of Interdistrict and Inter-state Variation in NorthEast India. In S. C. Nuna (eds.) Regional Disparity in the Educational Development. New Delhi: NIEPA, pp. 464.

Crop Calendar of major crops, Directorate of Economics and Statistics, Ministry of Agriculture, Govt. of India; http://eands.dacnet.nic.in/At_A_Glance2011/Appendix-IV.xIs(Accessed on 12.12.2016)

District Census Handbook of Bankura: Village and Town wise Primary Census Abstract, Part XII-B and Series-20. (2011).Available athttp://www.censusindia.gov.in/2011censu s/dchb/DCHB_A/19/1913_PART_A_DCHB_B ANKURA.pdf (Accessed on 1.03.2016)

Dubey, K. N. (1982). Regional Disparities in the Levels of Socio-economic Development in an Indian State: A Case Study of Uttar Pradesh, PhD thesis, Punjab University, Chandigarh.

Education Indicators Technical guidelines, UNESCO;

http://uis.unesco.org/sites/default/files/doc uments/education-indicators-technical-

guidelines-en.pdf(Accessed on 1.05.2016) Evaluation Report on Sarva Shiksha Abhiyan (May 2010): Programme Evaluation Organisation Planning Commission, Government of India.

Government of West Bengal, (2007).West Bengal Human Development Report, 2007.Development and Planning Department, GoWB, Kolkata.

Government of West Bengal (2007).District Human Development Report, Bankura. (2007). Development and Planning Department, GoWB, Kolkata.

International Rice Research Institute (IRRI) http://www.narc.gov.np/rice_knowledge_b ank/factsheet/boro.pdf (Accessed on 12.12.2016)

Ministry of Tribal Affairs, Government of India;

http://tribal.nic.in/Content/DefinitionpRrofil es.aspx (Accessed on 18.04.2016)

Mohapatra, A. C. (1993). Determinants of Regional Disparities in Literacy in NorthEast: Planning Strategies for Removal of Disparities. In S. C. Nuna (eds.) Regional Disparity in the Educational Development. New Delhi: NIEPA, pp. 476-485.

National Commission for Schedule Castes, Govt. of India; http://ncsc.nic.in/pages/view/73/68introduction (Accessed on 18.04.2016) 
Roy, Archana Kumar, Singh Pappu and Roy, Rahi, A. L. (1996). Literacy for the UN (2015). Impact of Rural-urban Labour Oppressed. In D. N. Thakur (eds.) Studies in Migration on Education of Children: A Case Educational Development: Primary Study of Left Behind and Accompanied Education and Adult Literacy, New Delhi: Migrant Children in India, 2(4), 17-34, DOI: Deep and Deep Publication, pp. 593. http://dx.doi.org/10.20896/saci.v2i4.74 